\title{
The Impact of the Prague Spring on the USSR
}

\author{
Zbigniew Wojnowski
}

The Prague Spring marked the end of de-Stalinisation in the USSR. ${ }^{1}$ Over the previous fifteen years, the Soviet leadership had searched for ways to rekindle popular faith in the communist system after the traumas of Stalinism. Following Nikita Khrushchev's 'Secret Speech' at the Twentieth Congress of the Communist Party of the Soviet Union in February 1956, rank-and-file party members were encouraged to take a more active role in debating and implementing policy. Most prisoners were released from the Gulag in the first few years after Stalin's death as the new leadership relied more on persuasion and material incentives, and less on terror and coercion, to mould people into Soviet citizens. Censorship was relaxed, though fundamental aspects of the political, social and economic system were still beyond criticism in the USSR's public culture. ${ }^{2}$ These ambitious attempts to foster new forms of 'participatory citizenship' were curtailed with Khrushchev's ouster from the Kremlin in October 1964. ${ }^{3}$ But until the Warsaw Pact invasion of Czechoslovakia, Leonid Brezhnev's team still saw gradual economic reform and limited intellectual and cultural openings as a means of winning popular legitimacy. ${ }^{4}$

The Soviet Union's relations with Czechoslovakia and other East European satellite states reflected the broader dynamics of de-Stalinisation. Czechoslovakia remained politically, militarily and economically dependent on the USSR. At the same time, the late 1950s saw the emergence of special organisations devoted to promoting new types of transnational contacts between the Soviet Union and Czechoslovakia. Their goal was to demonstrate the international success of Soviet-style socialism. Soviet travel to Eastern Europe was a particularly important means of fostering faith in the communist project among the population of the USSR: trips to the satellite states were meant to include ordinary blue-collar workers, eclipsing 'any significant expression of ethnic or national difference ... in favor of a shared socialist/working class identity'. ${ }^{5}$ Soviet and Czechoslovak citizens engaged with the transnational friendship project for a variety of reasons, ranging from personal memories of the Second World War 'to professional interests to attempts to further transnational friendships made in other contexts to a desire for goods and culture unavailable at home'. ${ }^{6}$ 
The 1950s and the 1960s also witnessed the rise of new transnational contacts that were beyond the Kremlin's control. ${ }^{7}$ Especially (though not exclusively) in the USSR's western borderlands, Soviet citizens learned about the outside world from western radio stations broadcasting into the country, as well as East European newspapers, radio and television. East European broadcasts and publications featured items that Soviet censors considered 'antisocialist'. ${ }^{8}$ At the same time, the Soviet leadership was reluctant to stop the flow of news from the the USSR's satellite states, lest socialist friendship be exposed as a mere propaganda façade. By the late 1960s, Soviet leaders looked upon a fast globalising world with apprehension. When Alexander Dubček launched his reforms in Czechoslovakia, people in the USSR were surprisingly well-informed about the momentous events across their western border.

As Soviet citizens commented on the Czechoslovak crisis widely, Thaw-era notions of what it meant to be Soviet and what it meant to be socialist crumbled. From the Politburo's perspective, the Czechoslovak events were part of a broader international crisis facing communism that encompassed student protests in Poland, escalating tensions with China and a break with Nicolae Ceauşescu's socialist Romania. ${ }^{9}$ In this context, Czechoslovakia represented the most sustained and ambitious attempt to reform a regime that very closely resembled the Soviet model. Dubček's experiment was thus a testing ground for Soviet policies and ideas. Commenting on the Prague Spring reforms and the Warsaw Pact invasion of Czechoslovakia, leaders and citizens of the USSR reflected not only on their country's foreign policy, but also on the extent to which it was possible to increase political participation, open borders and relax censorship without undermining party control over society and inducing instability. The Soviet-led invasion of Czechoslovakia was a clear sign that the Brezhnev leadership would no longer pursue or tolerate attempts at democratisation within the bloc's communist parties or in society more broadly. Ambitious attempts to increase citizens' participation in debating and implementing policy thus ended with a bang in August 1968.

This clear anti-reformist direction created deep rifts in Soviet society. Some citizens turned to illegal means to defend the de-Stalinisation agenda. At the same time, faced with a major crisis of the socialist system that challenged Soviet ideas of progress, leaders of the USSR were able to rally many citizens around the idea that Soviet interests had to be protected against the supposed chaos emanating from Eastern Europe, as well as a potential 'fifth column' at home. In various public forums, citizens underlined their loyalty to the Soviet homeland and its titular ethnic groups. While it is 
impossible to judge levels of genuine belief, these public articulations of Soviet patriotism shaped social and political dynamics in the USSR during the late 1960s. The 'search for socialism' that had animated state-society dynamics over the previous fifteen years was over in 1968. Instead, ethnically and geographically defined Soviet patriotism, often framed in xenophobic terms, became the main tool of social and political mobilisation in the USSR.

My analysis encompasses developments in Moscow, where the top Soviet leadership as well as members of the intelligentsia followed the Czechoslovak crisis in detail. But the chapter focuses in particular on Soviet Ukraine. Ukraine lay in the west of the USSR and it shared a border with Czechoslovakia. ${ }^{10}$ Its inhabitants were therefore very well-informed about the Prague Spring. In the borderland region of Transcarpathia, memories of Czechoslovak rule in the interwar period made the crisis seem very close to home. ${ }^{11}$ Moreover, the example of Czechoslovakia's rising autonomy from Moscow followed by a military crackdown on Dubček's reforms carried particular significance in the USSR's non-Russian periphery, which itself had a complicated relationship with the Soviet centre in Moscow.

\section{Official Reactions}

The Prague Spring sparked a crisis of identity among the Soviet leadership. Throughout the first half of 1968 , Brezhnev in particular was keen to salvage the idea that political and economic reform was possible in the Soviet bloc and, by extension, in the USSR itself. He was therefore reluctant to crack down on 'socialism with a human face' which promised to lend Soviet-style regimes new legitimacy. But other members of the Politburo were also painfully aware that Dubček's reforms challenged Soviet-made visions of what it meant to be socialist. The Warsaw Pact invasion of Czechoslovakia pushed Soviet leaders to search for new sources of legitimacy at home and abroad, as attempts to involve citizens in debating and implementing policy were now associated with chaos and violence.

In conversations with Soviet diplomats in Prague in early 1968, Dubček presented his reforms as a fight against 'violations of party discipline', excessive bureaucracy and attempts to concentrate all political power in the hands of just one individual. These ideas echoed Brezhnev's own slogans that helped him justify the overthrow of Khrushchev in $1964 .^{12}$ In January and February 1968, the Kremlin did not therefore express alarm at the unfolding events in Czechoslovakia. The tide turned in March when, concerned by the removal of former party leader Antonín Novotný from the office of president, major changes in Communist Party cadres and increasingly free mass media in Czechoslovakia, 
Moscow issued a stern warning to Prague. Even then, members of the Politburo insisted that some of the most confrontational phrasing prepared by Foreign Minister Andrei Gromyko and the head of the KGB Yurii Andropov be dropped from the letter they drafted. ${ }^{13}$ An eyewitness recalled 'long and heated' arguments in the Soviet Politburo during deliberations on the Czechoslovak crisis. ${ }^{14}$ Top Soviet leaders were clearly at a loss about how to interpret Dubček's policies. Prime Minister Alexei Kosygin, for example, was a very harsh critic of Czechoslovak reforms in March 1968, but seemed to take a more positive view of Dubček after a visit to Karlovy Vary in May. He continued to question the idea of a military intervention in Czechoslovakia at Politburo meetings: 'We will take our armies in, and then what?'. Even in early August, shortly before the invasion, Moscow harboured hopes that the Čierná-nad-Tisou agreements would help to avoid open confrontation with Czechoslovakia. ${ }^{15}$

Soviet leaders knew that their own legitimacy was at stake in Czechoslovakia. Albeit highly critical of the mooted idea to introduce a multi-party system in Czechoslovakia, Brezhnev still wanted inhabitants of the socialist camp to believe that communist parties and state institutions could bring more prosperity and opportunities for citizens to participate in power. ${ }^{16}$ In May 1968 , the head of the Supreme Soviet Nikolai Podgornyi was likewise alarmed that an overly heavy-handed approach in Czechoslovakia would convince 'enemies of socialism' that the system was broken. ${ }^{17}$ Further down the Communist Party hierarchy, after Khrushchev's economic policies that had effectively devolved much decision making to the non-Russian republics were reversed in $1965,{ }^{18}$ the Prague Spring was seen as a promising sign that political power might once again be de-centralised along national lines. Soviet Ukrainian party activists often travelled to Czechoslovakia in 1968 to gather information and influence Slovak politics in particular; many drew inspiration from the example of Slovakia successfully lobbying for more autonomy from Prague. ${ }^{19}$

Yet many influential Soviet leaders were early advocates of crushing Dubček's reforms. The foreign ministry, along with the KGB and the GRU (the organisation in charge of Soviet reconnaissance operations), were the main channels through which Politburo members learned about events across the border. From November 1967, they painted a dark picture of Czechoslovak politics, raising alarm about the relaxation of censorship in Czechoslovakia which, in their view, weakened communist ideology. Equally important, they associated freedom of speech with the rise of anti-Soviet stereotypes, stressing that the Czechoslovak mass media presented Soviet people as 'downtrodden and backward'. ${ }^{20}$ In contrast to the late 1950 s and early 1960 s, public debate was increasingly seen 
not as a means of fostering faith in socialism, but rather as a threat to the unity of the Soviet bloc. Moscow was much more preoccupied with the lack of censorship and emerging political pluralism in Czechoslovakia than about Ota Šik's explicitly market-oriented economic reforms. ${ }^{21}$

From the Kremlin's perspective, the political turmoil and new cultural openings of 1968 were a concern insofar as they threatened Czechoslovakia's place in the Warsaw Pact. The Defence Minister Andrei Grechko was especially worried about the spread of anti-Soviet propaganda among Czechoslovak soldiers. ${ }^{22}$ As the man who represented the Soviet Politburo in Prague during the invasion in August, General Kirill Mazurov, put it in an interview conducted over twenty years later: '[i]t was difficult for us to imagine that a bourgeois parliamentary republic could take shape along our borders, one flooded with West Germans and behind them, Americans. This was totally incompatible with the interests of the Warsaw Pact'. ${ }^{23}$ Less commonly, Politburo members expressed concern about the infrequent Czechoslovak irredentist claims to Soviet territory. In June 1968, for example, the Politburo informed Prague about their outrage at the pamphlets they discovered in Czechoslovakia. Their authors claimed that the region of Transcarpathia, annexed by the USSR at the end of the Second World War, should be returned to Czechoslovakia. ${ }^{24}$

In the course of 1968 , sceptical about the new participatory public culture across their western border, Soviet leaders grew ever more keen to constrain access to information and public debate in the USSR itself. The Ukrainian party boss Petro Shelest was especially vocal in condemning developments in Czechoslovakia, berating Brezhnev for indecisiveness during the crisis (later he even claimed that the Soviet First Secretary fainted when the decision to invade Czechoslovakia was taken). ${ }^{25}$ Like other leaders of territories bordering on Czechoslovakia, including Władysław Gomułka in Poland and Walter Ulbricht in East Germany, ${ }^{26}$ Shelest was alarmed by the potential spillover of the Czechoslovak crisis. He thus called for suppressing the flow of information from Czechoslovakia into the USSR's Ukrainian borderlands. ${ }^{27}$ The Soviet hardliners gained more traction with Brezhnev by mid-1968, as developments in Czechoslovakia seemed to slip out of Dubček's control. ${ }^{28}$ The limits of permissible expression shrank accordingly. Czechoslovak and Romanian publications were subjected to Soviet censorship in the summer of 1968, even though books and newspapers from East European socialist countries had previously been free from such controls. ${ }^{29}$ Censorship control over Soviet publications also grew harsher as the Czechoslovak events unfolded. ${ }^{30}$ 


\section{Search for Legitimacy}

The political and cultural shifts of 1968 , however, did not just entail limiting citizens' access to information. Rather, the Prague Spring sparked a search for redefining the USSR's relationship with its allies in Soviet public culture. Soviet propaganda drew on a sense of great power pride and ethnic prejudices to justify the USSR's continuing interference in Eastern Europe as it became clear that Soviet-style socialism had failed to create friendly relations between the USSR and Czechoslovakia. The prominence of geographically and ethnically-defined identities in Soviet public culture had farreaching implications for identity politics at home.

Even after the Warsaw Pact invasion of Czechoslovakia, officials in the USSR continued to present Soviet-style socialism as an ideology powerful enough to bridge national divisions and accommodate national differences. After a brief lull, the Soviet-Czechoslovak Friendship Society revived international travel between the two countries. In late 1968 and 1969, as Rachel Applebaum puts it, Soviet tourists visiting Czechoslovakia engaged in a quest for 'mutual understanding' with the Czechoslovak citizens they encountered. ${ }^{31}$ In order to justify the military invasion, the press frequently drew on the stock phrases about proletarian solidarities during official agitation meetings on Czechoslovakia. ${ }^{32}$ Still, painfully aware that citizens learned about the Czechoslovak crisis from foreign sources of information before the Soviet media, ${ }^{33}$ opinion leaders in the USSR were worried that slogans about international socialist friendship rang hollow in 1968. Czechoslovak broadcasts made it very clear that Dubček had a different interpretation of what it meant to be 'socialist' than his Soviet counterparts. ${ }^{34}$ Rifts in Soviet relations with the communist parties of France and Italy, as well as Romania and Yugoslavia, cast further doubt on the strength of friendly transnational ties grounded in a common ideological outlook. ${ }^{35}$ Before the invasion, with Czechs and Slovaks complaining about the USSR's control over their natural resources, the KGB wrote of 'peace and friendship' as meaningless phrases that masked much more 'messy' international relations. ${ }^{36}$ Doubts about the power of 'socialism' to capture popular imagination multiplied in August 1968. Following the military intervention, participants in public agitation meetings provocatively asked lecturers to name the leaders in Prague who had supposedly asked the USSR for military assistance, ${ }^{37}$ as it became very clear that these pro-Soviet Czechoslovak socialist forces had failed to materialise. ${ }^{38}$

For the Soviet regime, socialism thus turned from a legitimating discourse into a contested idea and even a symbol of foreign policy failures. For those who saw Dubček as a committed Leninist, the 
Soviet military intervention signalled deep rifts within the socialist movement. For those who believed that Czechoslovakia was overrun with counter-revolutionary forces, it was clear that Soviet-style socialism failed to spread across borders. This may partly explain why the Politburo approached the rhetoric of 'revolution' and 'communism' with great caution. In editing the appeal that pro-Soviet Czechoslovak forces sent to Brezhnev with a request for military assistance, Politburo members heeded the advice of the secretary in charge of ideology Mikhail Suslov and decided that it would be best not to refer to the alleged pro-Soviet Czechoslovak forces as 'revolutionary'. In another appeal written to citizens of Czechoslovakia on behalf of Warsaw Pact members concerned about the unfolding events in Prague, Soviet leaders addressed 'workers', 'peasants', 'the national intelligentsia', 'Czechs', and 'Slovaks', but decided to remove references to 'communist party members' as the progressive, pro-Soviet forces in Czechoslovakia. ${ }^{39}$ In defining 'us' versus 'them', the Politburo was more at ease with appealing to social and ethnic rather than political or ideological allegiances.

As the socialist ties that bound the USSR and Czechoslovakia were visibly shaken, the Soviet mass media evoked a sense of great power pride to justify the USSR's continuing interference in Eastern Europe. In this way, the mounting crisis in Czechoslovakia marked a return to geographically and ethnically defined patriotism that had helped mobilise citizens behind Stalinist policies. ${ }^{40}$ Amir Weiner shows that the memory of the Second World War was particularly crucial for legitimising the USSR's actions in Czechoslovakia. ${ }^{41}$ Moreover, the Soviet press defined the socialist camp as a union of closely-related Slavic nations, grounded in supposedly natural inborn affinities older than Soviet socialism. ${ }^{42}$ In line with these broader trends, the central Soviet newspaper Krasnaia zvezda (Red Star) described the concept of Central Europe as a hostile assault on natural affinities. The concern was that historians who wrote about 'Central Europe' implied that the Soviet satellite states (as well as western Ukraine) were part of the Habsburg and not the Russian historical sphere of influence. ${ }^{43}$ Although the Soviet Union's satellite states included countries with non-Slavic majority populations, Soviet propaganda cast Eastern Europe as a predominantly Slavic community, united against German and Jewish outsiders.

Simplistic xenophobic slogans played an important role in Soviet public culture during 1968. According to Polish diplomats in Moscow, the anti-Semitic speech which Władysław Gomułka delivered after the student protests in Poland found great resonance in the USSR itself. ${ }^{44}$ Along with other statements 
published in the USSR in the aftermath of the Polish student protests in March, the speech fanned the fear of '(West) German imperialism', 'Zionism', and 'cosmopolitanism' as destructive forces that threatened the Slavs of Eastern Europe. ${ }^{45}$ In the summer of 1968 , the Soviet media continued to mobilise popular fears of German 'revanchism'. They publicised proclamations by the organisations of Sudeten Germans who pressed the West German government not to recognise post-war borders, and emphasised that nationalists in Austria and West Germany would threaten the USSR itself if they gained control over Czechoslovakia. ${ }^{46}$ The Soviet news agency TASS framed the Warsaw Pact invasion of Czechoslovakia as part of an age-old European struggle for peace that predated the establishment of the USSR. ${ }^{47}$

Soviet propaganda raised anxieties about Czech and Slovak nationalism during 1968. Informing party activists about the unfolding developments in July 1968, for example, the Politburo wrote about the 'specificity' of Czechoslovakia and its communist party, underlining that the 'bourgeoisie' never emigrated after the establishment of socialism in the country in 1948. Class enemies had infiltrated the party and were now on course to restore capitalism in Czechoslovakia. The implication was clear: Czechs were inherently suspect, as even membership in the communist party was no sure sign of loyalty. In contrast, not only Soviet communists, but all 'Soviet people' were ready to defend revolutionary achievements. ${ }^{48}$ The language of socialism thus masked rather crude distinctions made on the basis of ethnicity and citizenship. Anti-Czechoslovak narratives were further promulgated after the invasion. For instance, the short documentary Counter-Revolution Shall Not Succeed (Kontrrevoliutsiia ne proidet), screened before feature films in Soviet cinemas, depicted foreigners across the border as dangerous radicals. ${ }^{49}$

Xenophobic incidents were likewise on the rise in late 1968 and 1969. When a group of sixty-one Czechoslovak miners and engineers from Ostrava came to Lviv to visit the Soviet soldiers whom they had supposedly befriended back home during the autumn of 1968, the trip took a nasty turn. One guest came up to a Czech woman who was dancing with a Soviet Army soldier, slapped her in the face and called her a 'Russian swine'. ${ }^{50}$ Similarly, after the series of anti-Soviet demonstrations that followed the infamous USSR-Czechoslovakia ice hockey matches in March 1969, Soviet citizens attended special informational meetings. They learnt about crowds of angry protesters who destroyed Aeroflot offices in Prague and, even worse, vandalised monuments commemorating Soviet soldiers who had 'liberated Czechoslovakia from fascism in 1945'. Although Dubček tried to dismiss these 
actions as isolated cases of hooliganism, Soviet agitators insisted that anti-Soviet nationalism was in fact widespread in Czechoslovakia, with right-wing forces infiltrating such 'socialist' institutions as the official trade unions. Propaganda further played on Soviet fears of encirclement, emphasising that anti-Soviet sentiment in Czechoslovakia was promoted by the USA, West Germany and China. ${ }^{51}$

The shifts in Soviet public culture that occurred in 1968 had far-reaching implications for identity politics at home. Evoking the supposedly eternal and natural ethnic bonds among Slavs, Soviet leaders were intolerant of any expression of complex, multi-national borderland identities. From their perspective, every political-administrative unit in the Soviet bloc and each resident of the socialist camp could be described in unambiguous national terms. The Soviet authorities looked upon national minorities with suspicion at a time when the nation turned into the primary locus of identity. They thus hoped to see the Slovaks curtail the activities of the Ukrainian minority in eastern Slovakia, concerned that their interpretation of what it meant to be Ukrainian undermined state-approved narratives of Ukrainianness promoted within the USSR itself. The KGB was particularly alarmed by the revival of the Greek Catholic Church in Czechoslovakia because this institution, banned in the USSR, was seen as a vehicle for articulating Ukrainian identities defined in opposition to the Soviet state. ${ }^{52}$ From the Soviet perspective, Slovakia would be a much more reliable neighbour if it was simply Slovak rather than multi-national. On the Soviet side of the border, non-titular ethnic groups without their own national republics came under suspicion. Most prominently, after the 1967 Six Days War, the ethnocentric turn in public culture fuelled anti-Semitic rhetoric in the USSR. ${ }^{33}$ During agitation meetings organised in 1968, participants asked many questions concerning the role of Jews in East European disturbances. ${ }^{54}$ For their part, likely in response to popular accusations of disloyalty, some Soviet citizens of Jewish origin found it important to emphasise publicly that they were in fact loyal to the USSR. ${ }^{55}$ As high-ranking Soviet officials such as Petr Demichev discussed both anti-Semitism and Zionism as problems plaguing the socialist camp, they revealed their own anti-Semitic prejudice: 'Zionist forces have become distinctly more active. The masses can feel it. In consequence, we can observe a backlash in the form of anti-Semitic moods', Demichev claimed in a conversation with a Polish diplomat in Moscow, blaming the rise of anti-Semitism on the Jews themselves. ${ }^{56}$ Furthermore, some Soviet citizens of Polish and Czech origin found it expedient to publicly highlight their alienation from their rebellious 'external homelands' as ethnicity turned into a marker of loyalty. ${ }^{57}$ 
With the importance of geographically and ethnically defined patriotism on the rise, the limits of permissible national expression shrank even among the non-Russian ethnic groups which had their own nationally-designated republics in the USSR. This represented a major departure from Thaw-era policies. During the early 1960s, the party leadership in Ukraine was surprised by levels of resistance to Russification and attempts to curtail the rights of the republics. In order to avoid an open confrontation with dissidents and to increase their own autonomy from Moscow, some party officials sought legitimacy within their republic by presenting themselves as Ukrainian national leaders. These communists expected a measure of support from members of the Politburo in Moscow. ${ }^{58}$ In 1968, portrayals of the Prague Spring acted as a warning against over-emphasising Ukrainian distinctiveness in the USSR. Federalism in Czechoslovakia was hardly discussed in the Soviet Ukrainian press in 1968 and 1969, and it did not figure at all in public anti-Czechoslovak polemics. Reports from agitation meetings show that residents of the republic asked about the relationship between Czechs and Slovaks over and over again, ${ }^{59}$ but it seems that party activists found the subject too sensitive to discuss publicly. 60 With the Slovaks striving towards greater autonomy in Czechoslovakia, the authorities wanted to prevent inhabitants of Ukraine from questioning the position of their own republic in the USSR. These developments fed into high politics in Soviet Ukraine. It is possible that Shelest's vocal condemnation of Dubček's reforms was an attempt to demonstrate to Moscow that his own limited endorsement of Ukrainian culture was different from Czechoslovak demands for more autonomy from Moscow. ${ }^{61}$ Still, developments in Czechoslovakia helped to discredit Shelest's relatively liberal national policy. In contrast, his main rival in Kyiv Volodymyr Shcherbyts'kyi had no scruples about subordinating the republic's interests to those of the Soviet state. As such, he was seen as more reliable by the Kremlin and his position in the Ukrainian party was strengthened during $1968 .{ }^{62}$

\section{A New Consensus}

The Brezhnev regime successfully redirected popular frustrations away from its own policies, and towards foreign and domestic 'enemies'. Many citizens embraced the state's patriotic rhetoric, rallying behind the Soviet state as a representative of their interests defined in opposition to 'nationalists' and 'imperialists' abroad, as well as ethnic minorities at home. Expressions of Soviet patriotism did not necessarily reflect genuine belief, but they shaped the parameters of Soviet public culture in 1968 . 
In various forums, as socialism turned into a contested notion during 1968, citizens underlined their loyalty to the Soviet vision of what it meant to be properly socialist. In May 1968, an engineer from Mukachevo, close to the Slovak-Ukrainian border, thus stated that his father had died in Czechoslovakia during the Second World War fighting for 'a life without the rich' for the Czechoslovak people. Now his achievements were being undermined, he despaired, because the Czechoslovak party was in no hurry to build socialism, and some of its members were even 'anti-communist'. ${ }^{63}$ Two months later, a pensioner from the Sumy region in northern Ukraine claimed that Dubček's democracy would mirror Masaryk and Beneš's pre-war 'bourgeois republic', with the 'working class' condemned to 'hunger, unemployment, executions and imprisonment'. It was necessary to increase 'revolutionary alertness', he concluded. ${ }^{64}$

More often, however, public statements of support for the USSR's policies in Czechoslovakia were underpinned by loyalty not to the party or the cause of building communism, but rather to the Soviet state framed in geographical and ethnic terms. Especially in the borderlands, Sovietness was defined in opposition to the supposedly threatening Czechs and Slovaks. In this vein, after 21 August two students from Uzhhorod wrote to their parents in Lviv and Kamianets-Podilskyi relaying rumours that the Czechs wanted Transcarpathia back. ${ }^{65}$ In preparation for what seemed to be impending war, some residents of Transcarpathia bought great quantities of soap, salt and matches, whilst others prepared to leave the region and escape eastwards. ${ }^{66}$ Fear of war, combined with memories of victory over Nazi Germany, framed citizens' public declarations of loyalty to the Soviet Union. A villager from Transcarpathia described his outrage at the slanderous claims broadcast by the West German radio station Deutsche Welle which attacked 'our party and state'. He followed this statement by an account of his native village in Volhynia, which was 'burned to the ground' by the Nazis, and ended by writing that (given the opportunity) he would avenge the death of his father. ${ }^{67}$ For many, Soviet policies had a distinctly personal dimension, as people who overtly supported the invasion of Czechoslovakia spoke about their friends and relatives in the army. ${ }^{68}$ The public seemed receptive to increasingly xenophobic official narratives in August 1968. According to local officials, inhabitants of Chernivtsi applauded the 'heroic acts' of the Soviet Army and reacted very vocally to images of 'sabotage' aimed at 'our soldiers' when they watched the propaganda film Counter-Revolution Shall Not Succeed. ${ }^{69}$

These statements were often painfully jingoistic and it is difficult to assess levels of genuine belief behind them. However, they should not be dismissed as mere conformity, for geographically and 
ethnically defined Soviet patriotism also framed criticism of Soviet foreign and domestic policies. At a time when Moscow still considered a range of options in Czechoslovakia, some citizens reportedly expressed a desire for more decisive military measures to be implemented. During an informal conversation with his colleagues that was later related to the KGB, for example, a teacher from Transcarpathia argued that it was necessary to install a new leadership in Prague which could then request Soviet military assistance. ${ }^{70} \mathrm{It}$ is, of course, hard to gauge how widespread such views were, and it is conceivable that Shelest devoted disproportionate attention to pro-interventionist sentiment in his reports in order to exert pressure on Moscow to suppress the Prague Spring. But similar statements were also recorded after the August invasion. Several participants in public meetings called for a still stricter policy in Eastern Europe, asking why the army did not invade Romania. The KGB classified such views as 'criticism'. ${ }^{71}$ Citizens also articulated disappointment with the 'softness' of the Soviet occupation in Czechoslovakia. ${ }^{72}$ At agitation meetings in Zaporizhzhia, for example, members of the audience asked about the USSR'S failure to locate and destroy the underground radio stations in Czechoslovakia with all the advanced technology at its disposal. ${ }^{73}$

Citizens further expressed isolationist sentiments at odds with the USSR's continuing interference in East European politics. For example, the notion that the USSR should look after its own interests fuelled anti-war opinions in Soviet Ukraine. In correspondence with Moscow, Shelest reported the views of women collective farmers from a village in Transcarpathia who complained that their husbands were drafted into the army in the midst of spring field works, just because the Czechoslovak leaders were not able to cope with their own problems. ${ }^{74}$ Keen to ensure that citizens perceive Soviet socialism as a successful system with global appeal, some opinion leaders were alarmed when participants in public meetings suggested that Soviet interests did not coincide with those of the USSR's socialist allies. In Poltava, for example, a non-party collective farmer stated that all of Eastern Europe 'feeds off us', echoing more widespread complaints about Soviet subsidies to the socialist satellite states, ${ }^{75}$ but he supposedly 'understood his mistake' after the deputy head of a local council visited the collective farm to explain the intricacies of 'internationalist help'. ${ }^{76}$ Soviet patriotism defined in opposition to the socialist states of Eastern Europe helped citizens express diverse and even contradictory opinions about the desirable direction of the USSR's foreign policy.

Public discussions of the Czechoslovak crisis further provided a forum for criticising the Soviet mass media. Soviet institutions and the debates about the Prague Spring which they organised 
allowed citizens to build social and political capital. Speakers at agitation meetings typically acted as leaders of public opinion at home, promising to ensure that members of their local communities would toe the official line. ${ }^{77}$ These self-proclaimed leaders of popular opinion sometimes criticised the Soviet authorities for failing to provide enough information about the unfolding events. After the publication of the speech by the Polish communist leader, Gomułka, in which he blamed Jews for student unrest in Poland, some citizens demanded that a similarly clear statement should be produced with regards to Czechoslovakia. ${ }^{78}$ During the highly-controlled public meetings held to discuss the Prague Spring, citizens further picked up on inconsistencies in Soviet mass media coverage of Czechoslovakia. ${ }^{79}$ Some self-identified Soviet patriots claimed that incomplete information about the situation in Czechoslovakia was conducive to the appearance of harmful information and rumours. ${ }^{80}$ In July 1968 , for example, the KGB reported that students, teachers and other employees of the Odessa civil engineering institute complained that the secrecy surrounding the Czechoslovak events fuelled the popularity of hostile foreign radio stations, proposing that newspapers should publish short information about the course of events on a day-to-day basis. ${ }^{81}$ They were not dissidents opposed to Brezhnev's new course, and indeed they embraced the language of xenophobia that overcame the socialist camp in the late 1960s, but they still claimed the right to voice limited criticism of how Moscow handled information about the unfolding crisis.

From the Soviet leaders' point of view, censorship was not a sufficient means of keeping the population in cheque. Soviet patriotism defined in geographical and ethnic terms provided a powerful legitimating discourse for Brezhnev at the height of the Czechoslovak crisis, but it also pushed the Kremlin to reflect on the need to find new ways of providing information to loyal and engaged citizens.

\section{Dissent}

Brezhnev's fears that the crushing of Dubček's reforms would shake popular faith in the ability of Soviet institutions to evolve and better represent society's interests were not entirely unfounded. The Warsaw Pact invasion of Czechoslovakia was an important impetus for the growth of the Soviet dissident movement, whose members no longer found it possible to work within the confines of official culture to achieve their political goals. 'Dissent' refers to those opinions that Soviet leaders classified not merely as 'mistaken' or 'harmful', but outright 'illegal'. The KGB registered such dissenting voices among university students, members of the creative intelligentsia, soldiers and members of the Jewish minority, with most reports concentrating on citizens who did not belong to the communist 
party. ${ }^{82}$ Dissidents were few and far between, but most expressed a surprisingly coherent set of views, arguing that the USSR's great power nationalist politics represented a betrayal of socialist ideals. They sometimes echoed 'loyal' criticism of Soviet policy, criticising the invasion of Czechoslovakia and calling for more information to be provided to citizens. However, dissident views were underpinned by the belief that Dubček, and not Brezhnev, had the right idea about how to fix Soviet-style regimes. Soviet leaders and dissidents themselves knew full well that such views were now firmly outside the limits of the permissible.

Soviet intellectuals concerned about creeping 're-Stalinisation' of the socialist camp saw the Prague Spring as a rallying call for defending civic rights at home and abroad. Most famously, seven individuals gathered on Red Square in Moscow on 25 August 1968. They carried banners calling for the USSR to withdraw its armies from Prague, and underlining that they were fighting 'for your freedom and ours'. The protesters were brutally punished: two ended up in a labour camp, three were exiled from Moscow and one was sent to a mental hospital. Natalia Gorbanevskaia, who was still breast-feeding her small child at the time, was released. She played a leading role in establishing and running the samizdat publication The Chronicle of Current Events (Khronika tekushchikh sobytyi). ${ }^{83}$ Publicising statements by Soviet intellectuals and translations of Czechoslovak documents, The Chronicle turned into a source of news about the unfolding events at home and abroad and thus helped to shed dissent of its predominantly literary character in $1968 .{ }^{84}$

For Soviet dissidents, civic rights were tied intimately with freedom of speech. They drew on Khrushchev-era narratives of 'citizenship' (grazhdanstvennost'), ${ }^{85}$ bemoaning the fact that citizens' ability to participate in politics was ever more severely curtailed. In an attempt to evaluate the Czechoslovak events, many samizdat materials emphasised that 'freedom of expression' was the only guarantee of democracy and economic progress in the Soviet bloc. ${ }^{86}$ They likewise warned 'all citizens' that silence had already led to one disaster: the rise of Stalinism. ${ }^{87}$ Dissidents thus emphasised that residents of the USSR had a social and political responsibility to criticise the party leadership, but they were far from questioning the legitimacy of the Soviet state as such. Rather, they imagined themselves as part of a distinctly 'Soviet' community of citizen-activists. In this vein, an inhabitant of Dnipropetrovsk complained about the lack of information concerning demonstrations in Poland and changes in Czechoslovakia in the official press and on television. He sarcastically recalled how Soviet leaders kissed Novotný in front of cameras earlier, yet now could not find words 
to defend him (he suggested that perhaps they should have kissed him behind closed doors to make it more pleasant for everyone). His letter was very confrontational and he stated that the press was afraid to publish news from Eastern Europe lest Soviet students be inspired to protest against censorship, concentration camps or unfair trials. ${ }^{88}$

Dissent never translated into organised opposition to the Soviet state. But neither was postPrague non-conformity confined to a mere handful of Moscow intellectuals who published in samizdat. Liudmila Alekseeva documented several instances where citizens collected signatures under proDubček petitions or simply refused to vote on resolutions approving the Soviet invasion of Czechoslovakia at public meetings held across the USSR. ${ }^{89}$ The Ukrainian historian Volodymyr Dmytruk has also shown that views explicitly critical of Soviet policies in 1968 were registered throughout Soviet Ukraine. ${ }^{90}$ Sending anonymous letters and spreading illegal pamphlets, dozens of people embodied active resistance to the state's attempts at curtailing public debate. ${ }^{91}$ Party and KGB reports suggested that many non-conformists in the provinces and in the non-Russian parts of the USSR saw themselves as part of the same culture of dissent as their Moscow counterparts, citing the example of a student from Lviv who claimed that her friends should follow the example of Moscow dissidents. ${ }^{92}$

Non-conformist critiques of Soviet policies in Czechoslovakia were often explicitly grounded in socialist ideas. As self-proclaimed 'communists', ${ }^{93}$ many samizdat authors underlined their commitment to Dubček's reform socialism. They reprinted the Czechoslovak party's Action Programme from April 1968. The Soviet Union should learn how to build socialism from the Czechs read the four leaflets discovered in Chernihiv on 24 August - as the struggle in Czechoslovakia was not a fight between communism and capitalism, but rather a battle between new and old ideas within socialism. ${ }^{94}$ For those citizens who believed that the Kremlin betrayed the socialist cause in 1968 , real socialism was still embodied by some members of Brezhnev's own team. An anonymous letter from Zhdanov (Mariupol) in the Donetsk region condemned the 'bandit' invasion of Czechoslovakia and Brezhnev's 'revisionist' system, ending in gripping slogans: 'Out with Brezhnev! Long live Kosygin!'95 The authors did not explain why they held a positive opinion of the Soviet Prime Minister, but it is likely that they associated him with the abortive economic reforms of the mid-1960s which represented the last concerted attempt by the Kremlin to improve the functioning of Soviet institutions. ${ }^{96}$ 
Underground publications attacked the Warsaw Pact invasion of Czechoslovakia as an expression of 'imperialism', quite unbecoming of a socialist state committed to de-colonisation and internationalist friendship. ${ }^{97}$ In this vein, in July 1968 a self-styled 'group of honest communists' penned an open letter expressing the hope that the USSR would not risk discrediting itself "by invading a brotherly country'. ${ }^{98}$ Such views were often underpinned by anti-capitalist sentiment and continuing faith that Soviet-style socialism offered an attractive alternative path to modernity. Official reports quoted dozens of individuals who claimed that the intervention would weaken the communist movement in the whole world. ${ }^{99}$

The national question acquired a new urgency for dissidents as the limits of permissible nonRussian expression in the USSR shrank. Throughout the latter half of the 1960s, 'ethnic minority samizdat championed "genuine socialism" and "the restoration of Lenin's norms"' as a guarantee of greater national autonomy for republics in the USSR. ${ }^{100}$ In line with this, during the Prague Spring and its aftermath, some authors who published their views in the underground sought to defend 'Ukrainian rights', but also underlined their commitment to the Soviet Union and its official ideology. For example, an anonymous member of the Ukrainian writers' union distributed a letter among Soviet citizens, in which he or she commented at length on the situation in Czechoslovakia, as well as complained that the Soviet authorities were prejudiced against Ukrainian culture. Although the author was critical of Soviet nationalities policy, he or she still appealed to an official Soviet institution, the writers' union, to rectify the problem. ${ }^{101}$

\section{Anti-Soviet Nationalism}

It was mostly in the USSR's western borderlands that some residents went further and rejected the Soviet state and socialism in its entirety, rather than calling for the reform of the system. On 27 August, the Lviv regional party secretary claimed that 'nationalist' and anti-Soviet elements had intensified their hostile activities after the Warsaw Pact invasion of Czechoslovakia. ${ }^{102}$ At the height of the Prague Spring, the national solution was the most immediately obvious alternative to Soviet socialism for those citizens who rejected existing state structures. For instance, the KGB quoted a man from Stryi who claimed that the only way to solve the Czechoslovak problem was to grant 'freedom and independence' to all peoples in Eastern Europe, including Ukraine. ${ }^{103}$ This type of dissidence was not new in 1968, but rather represented continuities from earlier Ukrainian nationalist resistance to the USSR which was now weaker than at any point since the (re-)establishment of 
Soviet rule in the region during the Second World War. ${ }^{104}$ At least in the KGB's view, explicitly antiSoviet attitudes were mostly confined to individuals who had already developed a hostile relationship with the central ? authorities, with many having spent time in the Gulag for nationalist resistance to Soviet rule during and in the immediate aftermath of the Second World War. ${ }^{105}$ This suggests perhaps that the Prague Spring emboldened citizens with anti-Soviet convictions, but did not in fact increase the reach or affect the claims of anti-Soviet Ukrainian nationalism.

Anti-Soviet Ukrainian nationalism carried a range of different connotations. Anecdotal evidence suggests that in some cases it framed explicit calls for inter-ethnic violence. For instance, a metal worker from Lviv boasted that he had identified a house belonging to a Russian man in order to occupy it during the coming war. ${ }^{106}$ For others, anti-Russian nationalism helped frame economic complaints. Immediately after the invasion, an employee of a furniture factory in Chernivtsi stated that the 'Moskali' (a derogatory term for Russians) prevented the people of Czechoslovakia from 'living well', ${ }^{107}$ and a local resident claimed that the Ukrainians would be richer had it not been for fifty years of 'Muscovite oppression'. ${ }^{108}$ In some cases, nationalism was associated with support for private ownership. A woman employed at the bread factory in Uzhhorod stated that 'the Russians take everything away'. At the suggestion that it was still better to live under the Russians than the Germans, she retorted that the Germans would 'give people their land'. ${ }^{109}$ Finally, anti-Soviet Ukrainian nationalism helped citizens articulate opposition to religious oppression in the USSR. In particular, the legalisation of the Greek Catholic Church in Czechoslovakia during 1968 emboldened some faithful in Ukraine to call for similar measures at home. ${ }^{110}$

\section{Conclusion}

The Prague Spring marked a shift in Soviet identity politics. The events of 1968 made it abundantly clear that socialist allegiances were not tantamount to loyalty to the Soviet state and its titular ethnic groups. In the search for popular legitimacy, leaders of the USSR downplayed the internationalist ideas of the previous decade, when Khrushchev sought to rekindle popular faith in socialism as an ideology that united class-conscious, ideologically-committed people across borders. This is because the idea that socialist institutions would involve citizens in debating and implementing policy, or that socialism would help to construct a new type of international relations based on anti-imperialist commitments, was largely discredited by 1968 . 
Expression of 'socialist' identities was now largely confined to underground culture. The few, but surprisingly, vocal proponents of reform turned to illegal means such as unsanctioned demonstrations, underground publications and illegal pamphlets to defend the now largely abandoned de-Stalinisation agenda. They called for 'openness' and 'spiritual renewal' of Soviet society, demanded a return to 'Leninist' nationalities policy and criticised Brezhnev's 'imperialist' foreign policy. Bar a few scattered calls for independence from the USSR in the western borderlands, dissenting voices did not normally echo ideas of anti-Soviet nationalism or a sense of cultural and historical distinctiveness that Amir Weiner focuses on in his study of territories incorporated into the USSR after 1939.111 Rather, dissent was mostly grounded in a sense of Soviet patriotism that underpinned demands for political representation, access to information and freedom of speech. The geography of dissent in 1968 did not therefore conform to the stereotypical division into unstable borderlands and a compliant centre. This may partly explain why, some twenty years later, ideas about reforming socialism inspired by the Prague Spring entered the USSR's mainstream culture as Mikhail Gorbachev sought once again to radically overhaul the Soviet system. ${ }^{112}$

Yet it would be a mistake to assume that citizens lost faith in the ability of the Soviet state to represent their interests because they could no longer debate what socialism was or what communism should be; or to argue that residents of the USSR only remained acquiescent due to Brezhnev's material handouts. ${ }^{113}$ After the Prague Spring buried the Soviet Thaw, many inhabitants of the USSR did not see the Soviet state as an 'aging revolution' that had lost its impetus, but rather as an embodiment of their ethnically and geographically defined interests. ${ }^{114}$ Although it is impossible to judge levels of genuine belief behind public statements of approval for Soviet foreign policy in 1968, ethnically and geographically defined Soviet patriotism was a powerful tool that helped citizens manifest their patriotic credentials and thus improve their social standing and even to voice limited criticism of official policy.

Far from signalling the beginning of 'stagnation', the Czechoslovak crisis pushed Soviet leaders to search for new ways of shaping state-society dynamics in the USSR. The Prague Spring highlighted the urgent need to develop Soviet television that would help isolate citizens from harmful foreignproduced information and ideas. ${ }^{115}$ After the upheavals of 1968, Soviet and East European leaders did not close borders between the USSR and its satellite states. On the contrary, transnational cultural and social ties grew over the 1970s. As faith in the power of socialism to bind the USSR and 
its allies crumbled, Soviet media professionals developed new types of popular culture that lent Eastern Europe a great degree of cultural integrity, and East European organisations developed ties and infrastructure that allowed for the rise of international tourism on an unprecedented scale. But Eastern Europe was increasingly defined not as a 'socialist commonwealth' united by left-wing values and ideas, but rather as a confederation of closely related ethnic groups that looked to Moscow for protection against Western European and American aggression. ${ }^{116}$

\section{Notes}

${ }^{1}$ Some ideas and short extracts of this chapter have previously appeared in Z. Wojnowski, The Near Abroad: Socialist Eastern Europe and Soviet Patriotism in Ukraine, 1956-1985 (Toronto, 2017).

${ }^{2}$ For example, see J. Fürst, P. Jones and S. Morrissey, 'The Relaunch of the Soviet Project, 19451964', Slavonic and East European Review, vol. 86, no. 2 (2008), pp. 201-7.

${ }^{3}$ On the shrinking limits of the permissible, see D. Kozlov, The Readers of Novyi Mir: Coming to Terms with the Stalinist Past (Cambridge, MA, 2013), pp. 239-62.

4 J. Suri, 'The Promise and Failure of "Developed Socialism": The Soviet "Thaw" and the Crucible of the Prague Spring, 1964-1972', Contemporary European History, vol. 15, no. 2 (2006), pp. 138, 148, 150-3.

${ }^{5}$ A. Gorsuch, All This is Your World: Soviet Tourism at Home and Abroad after Stalin (Oxford, 2011), pp. $88,106-10$.

6 R. Applebaum, 'The Friendship Project: Socialist Internationalism in the Soviet Union and Czechoslovakia in the 1950s and the 1960s', Slavic Review, vol. 74, no. 3 (2015), p. 507.

7 See A. Gorsuch and D. Koenker, 'Introduction: The Socialist 1960s in Global Perspective', in A. Gorsuch and D. Koenker (eds), The Socialist Sixties: Crossing Borders in the Second World (Bloomington, IN, 2013), pp. 1-21. 
${ }^{8}$ A. Weiner, 'Déjà Vu All Over Again: Prague Spring, Romanian Summer, and Soviet Autumn on Russia's Western Frontier', Contemporary European History, vol. 15, no. 2 (2006), pp. 172-4.

${ }^{9}$ On Romania, see Calin Goina's chapter in this volume; Weiner, 'Déjà Vu', pp. 164-71. On the repercussions of the Polish crisis, see Wojnowski, The Near Abroad, pp. 106, 112, 114, 121-3, 126-7. $10 \mathrm{O}$. Bazhan edited a fascinating collection of KGB reports on popular opinion about the Prague Spring in Soviet Ukraine. See O. Bazhan (ed.), "'Praz'ka Vesna" u dokumentakh Galuzevoho derzhavnoho arkivu Sluzhby Bezpeky Ukrainy', Z arkhiviv VUChK-GPU-NKVD-KGB no. 1-2 (2008), pp. 54-137.

${ }^{11}$ On the importance of Transcarpathia during the Prague Spring, see Weiner, 'Déjà Vu', pp. 174-6.

12 O. Pavlenko, 'Sovetskie informationno-analiticheskie i operativnye materialy po chekhoslovatskomu krizisu 1968 goda', in N. G. Tomilina et al. (eds), Prazhskaia vesna i mezhdunarodnyi krizis 1968 goda: stat'i, issledovaniia, vospominaniia (Moscow, 2010), p. 61.

${ }^{13}$ M. Prozumenshchikov, "Vy poimete, chto my ne imeli drugogo vykhoda". Problemy razrabotki i priniatiia reshenii vysshim sovetskim rukovodstvom v khode chekhoslovatskogo krizisa 1968 goda', in Tomilina, Prazhskaia vesna: stat'i, pp. 19-20.

14 'Memoir of Andrei Aleksandrov-Agentov on Internal Soviet Deliberations about Czechoslovakia (excerpts)', in J. Navrátil et al. (eds), The Prague Spring 1968: A National Security Archive Documents Reader (Budapest, 1998), p. 102.

${ }^{15}$ Prozumenshchikov, '“Vy poimete”', pp. 20-1, 32-3.

16 Suri, 'The Promise', pp. 138, 148, 150-3; Pavlenko, 'Sovetskie informatsionno-analiticheskie i operativnye materialy', p. 50.

17 Prozumenshchikov, "'Vy poimete"', pp. 21-2.

18 On the fight against 'localism', see A. Nove, An Economic History of the USSR, 1917-1991 (London,1992), p. 368.

${ }^{19}$ G. Hodnett and P. Potichnyj, The Ukraine and the Czechoslovak Crisis (Canberra, 1970), pp. 11617.

${ }^{20}$ Pavlenko, 'Sovetskie informatsionno-analiticheskie i operativnye materialy’, pp. 50, 59.

${ }^{21}$ Prozumenshchikov, “'Vy poimete"', p. 26.

22 Prozumenshchikov, “'Vy poimete”', p. 20.

23 'The Recollections of Kirill Mazurov', in Navrátil et al. (eds), The Prague Spring, p. 434. 
24 'Postanovlenie Politbiuro TsK KPSS "V svyazi s rasprostraneniem v ChSSR "Obreshcheniia" tak nazyvaemogo "Komiteta Deistviia za demokraticheskuiu sotsialisticheskuiu Chekhoslovakiiu, granitsy i territoriia kotoroi byli ustanovleny 50 let nazad"', 18 June 1968, in N. G. Tomilina et al. (eds), Prazhskaia vesna i mezhdunarodnyi krizis 1968 goda: dokumenty (Moscow, 2010), p. 99.

${ }^{25} \mathrm{P}$. Shelest, Spravzhnii sud istorii shche poperedu. Spohady, shchodennyky, dokumenty, materialy edited by lurii Shapoval (Kyiv, 2003), p. 331.

${ }^{26}$ Pavlenko, 'Sovetskie informatsionno-analiticheskie i operativnye materialy', p. 72.

${ }_{27}$ M. Kramer, 'The Czechoslovak Crisis and the Brezhnev Doctrine' in C. Fink et al. (eds), 1968: The World Transformed (Cambridge, 1998), p. 144; Tsentral'nyi Derzhavnyi Arkhiv Hromads'kykh Ob"ednan' Ukrainy, Kyiv (TsDAHO), f. 1, op. 25, s. 28, ark. 98.

${ }^{28}$ Suri, 'The Promise', pp. 146-7.

29 O. Lavinskaia, 'Tsenzura v SSSR I ogranicheniia informatsii o sobytiiakh v Chekhoslovakii', in Tomilina et al. (eds), Prazhskaia vesna: stat'i, p. 133.

30 V. Baran, Ukraina: Novitnia istoriia (Lviv, 2003), p. 283.

${ }^{31}$ R. Applebaum, 'A Test of Friendship: Soviet-Czechoslovak Tourism and the Prague Spring', in Gorsuch and Koenker (eds), The Socialist Sixties, pp. 213-32.

${ }^{32}$ For example, Digest of Soviet Ukrainian Press 12:10: H. Nikol'nikov, 'The Struggle of V. I. Lenin and the CPSU for Consolidating the Principles of Proletarian Internationalism', Radians'ka Ukraina, 3 September 1968.

${ }^{33}$ Derzhavnyi Arkhiv Lvivskoi Oblasti, Lviv (DALO), f. P3, op. 10, s. 248, ark. 3-4, 87-89; TsDAHO, f. 1, op. 25, s. 14, ark. 26-30; TsDAHO, f. 1, op. 25, s. 32, ark. 15-20; Rossiiskii Gosudarstvennyi Arkhiv Noveishei Istorii, Moscow (RGANI), f. 1, op. 60, d. 28, II. 65-6.

${ }^{34}$ TsDAHO, f. 1, op. 25, s. 37, ark. 9-12.

35 Prozumenshchikov, “'Vy poimete"', p. 31.

${ }^{36}$ Pavlenko, 'Sovetskie informatsionno-analiticheskie i operativnye materialy', p. 52.

37 TsDAHO, f. 1, op. 25, s. 38, ark. 21-24, 36-39; Document 48, 'Informatsiia sekretaria MGK KPSS V.

V. Grishina v TsK KPSS ob otklikakh trudiashchikhsia g. Moskvy v svyazi s polozheniem v Chekoslovakii', 22 August 1968, in L. Velichanskaia (ed.), Chekhoslovatskii krizis 1967-69 gg v dokumentakh TsK KPSS (Moscow, 2010), p. 868.

${ }^{38}$ Prozumenshchikov, “'Vy poimete"', p. 37. 
${ }^{39}$ Prozumenshchikov, "“Vy poimete”', p. 36.

40 T. Martin, The Affirmative Action Empire: Nations and Nationalism in the Soviet Union, 1923-1939 (Ithaca, NY, 2001), p. 450.

${ }^{41}$ Weiner, 'Déjà Vu', pp. 186-9.

42 Wojnowski, The Near Abroad, p. 148.

${ }^{43}$ Current Digest of the Soviet Press (CDSP) 20:21, 12 June 1968: V. Kozyakov, 'What the American Policy of "Building Bridges" Aims At', Krasnaia zvezda, 24 May 1968.

${ }^{44}$ Archiwum Akt Nowych, Warsaw (AAN), z.1354, s.XIA, t.84, ss. 269-70.

${ }^{45}$ CDSP 20:14, 24 April 1968: 'Speech by Comrade W. Gomułka at Meeting with Warsaw Party Aktiv',

Pravda, 22 March 1968; B. Kowalski, 'On Certain Theses of Israeli and West German Propaganda', Literaturnaia gazeta, 3 April 1968.

${ }^{46}$ A. Filitov, 'SSSR, FRG i Chekhoslovatskii krizis 1968 goda', in Tomilina et al. (eds), Prazhskaia vesna: stat'i, p. 82.

47 'Postanovleniie Politbiuro TsK KPSS "O zaiavlenii TASS"', 19 August 1968, in Velichanskaia (ed.), Chekhoslovatskii krizis, p. 201.

48 'Postanovleniie Politbiuro TsK KPSS "Ob informatsii partiinogo aktiva o sobytiiakh v Chekhoslovakii”', 7 July 1968, in Velichanskaia (ed.), Chekhoslovatskii krizis, pp. 119-20.

49 Wojnowski, The Near Abroad, pp. 119-20.

50 TsDAHO, f. 1, op. 25, s. 255, ark. 2-5.

51 M. Prozumenshchikov, 'Skol'zkii led "Prazhskoi vesny", ili o roli sporta v istorii sovetskochekhoslovatskikh otnoshenii', in Tomilina et al. (eds), Prazhskaia vesna: stat'i, p. 148; 'Postanovleniie Politbiuro TsK KPSS "Ob informatsii po Chekhoslovakii"', 23 March 1968, in Tomilina et al. (eds), Prazhskaia vesna: dokumenty, p. 27; 'Postanovleniie Politbiuro TsK KPSS "Ob informatsii dlia partiinogo aktiva o sobytiiakh v Chekhoslovakii"', 10 April 1969 in Velichanskaia (ed.), Chekhoslovatskii krizis, pp. 526-8.

52 Hodnett and Potichnyj, The Ukraine, pp. 117-19.

53 Weiner, ‘Déjà Vu’, p. 180.

54 TsDAHO, f.1, op.25, s.14, ark. 131-133.

55 Derzhavnyi Arkhiv Odes'koi Oblasti, Odesa (hereafter, DAOO), f.P11, op.19, s.702, ark. 4-11. As Yaacov Ro'i argues in his study of Soviet Jewish reactions to the 1967 Six Days War, statements like these were likely underpinned by Jewish fear of anti-Semitism. '[I]t is reasonable to assume that many Jews, especially older ones who remembered the propaganda campaigns of early 1949 and early 1953, genuinely feared the negative results of the Six Day War might have on them and made every 
effort to dissociate Soviet Jewry from the activity and policy of the Israeli government and to condemn them'. 'The Soviet Jewish Reaction to the Six Day War' in Y. Ro'i and B. Morozov (eds), The Soviet Union and the June 1967 Six Day War (Stanford, 2008), 258.

56 AAN, z.1354, s.XIA, t.84, s. 308.

57 DAOO, f. P11, op. 20. s. 88, ark. 15-26; TsDAHO, f. 1, op. 25, s. 37, ark. 93.

${ }^{58}$ B. Lewytzkyj, Politics and Society in Soviet Ukraine, 1953-80 (Edmonton, 1987), pp. 100, 134.

59 TsDAHO, f. 1, op. 25, s. 14, ark. 131-133; TsDAHO, f. 1, op. 25, s. 35, ark. 6-7; TsDAHO, f. 1, op. 25, s. 39 , ark. 10-14.

60 Hodnett and Potichnyj, The Ukraine, pp. 116-17.

61 Hodnett and Potichnyj, The Ukraine, p. 78; Lewytzkyj, Politics and Society, p. 119; Kramer, 'The Czechoslovak Crisis', p. 144.

62 Lewytzkyj, Politics and Society, p. 204.

63 TsDAHO, f. 1, op. 25, s. 28, ark. 102-112.

64 TsDAHO, f. 1, op. 25, s. 35, ark. 6-7.

65 TsDAHO, f. 1, op. 25, s. 28, ark. 102-112.

${ }^{66}$ Bazhan, '"Praz'ka Vesna"', pp. 70-1, 73, 105; TsDAHO, f. 1, op. 25, s. 28, ark. 102-112.

${ }^{67}$ RGANI, f. 5, op. 60, d. 26, II. 160-72.

${ }^{68}$ DALO, f. 3, op. 10 , s. 248 , ark. 20-23.

69 TsDAHO, f. 1, op. 25, s. 33, ark. 111-115.

70 TsDAHO, f. 1, op. 25, s. 28, ark. 12-13.

71 TsDAHO, f. 1, op. 25, s. 39, ark. 10-14.

72 Derzhavnyi Arkhiv Kyivs'koi Oblasti, Kyiv, f. P5, op. 7, s. 822, ark. 42-43.

73 TsDAHO, f. 1, op. 25, s. 39, ark. 10-14.

74 TsDAHO, f. 1 , op. 25, s. 28, ark. 102-112.

${ }^{75}$ For more examples of complaints about Soviet exports, see Wojnowski, Near Abroad, pp. 15, 27, 44-5, 182, 191-3, 205.

76 TsDAHO, f. 1, op. 25, s. 39, ark. 142-144.

77 Wojnowski, The Near Abroad, pp. 116-19.

78 DAOO, f. P11, op. 19, s. 702, ark. 4-11.

79 TsDAHO, f. 1, op. 25, s. 14, ark. 131-133.

${ }^{80}$ Bazhan, '"Praz'ka Vesna"', p. 86.

${ }^{81}$ DAOO, f. 11 , op. 20 , s. 88 , ark. 15-26. 
82 Wojnowski, The Near Abroad, pp. 125-8.

${ }^{83}$ L. Alekseeva, Istoriia inakomysliia v SSSR: Noveishii period (Benson, VT, 1984), pp. 264-5.

${ }^{84}$ Khronika tekushchikh sobytii (KhTS), 31 December 1968.

${ }^{85}$ For a discussion of grazhdanstvennost', see S. Costanzo, 'Amateur Theatres and Amateur Publics in the Russian Republic, 1958-71', Slavonic and East European Review, vol. 86, no. 2 (2008), p. 394. ${ }^{86}$ KhTS, 30 June 1969.

87 Sobranie dokumentov Samizdata (SDS), Document AS69: Valentin Komarov, 'Otkrytoe pis'mo v sviazi s okkupatsiei Chekhoslovakii'.

${ }^{88}$ RGANI, Moscow, f. 5, op. 60, d. 26, Il. 39-71.

${ }^{89}$ Alekseeva, Istoriia inakomysliia, pp. 264-5.

90 V. Dmytruk, Ukraina ne movchala: Reaktsiia ukrains'koho suspil'stva na podii 1968 roku v Chekhoslovachchyni (Kyiv, 2004).

${ }^{91}$ Bazhan, 'Praz'ka Vesna"', pp. 111-16.

92 Wojnowski, The Near Abroad, p. 128.

${ }^{93}$ KhTS, 28 February 1970.

${ }^{94}$ TsDAHO, f. 1, op. 25, s. 31, ark. 141-143.

${ }^{95}$ Bazhan, '"Praz'ka Vesna"', p. 93.

96 For a discussion of the Kosygin reforms, see A. Shubin, Ot zastoia $k$ reformam: SSSR $v$ 1917-85 $g g$ (Moscow, 2001), p. 119.

${ }_{97}$ KhTS, 31 October 1969; KhTS, 31 August 1970.

98 SDS, Document AS108: P. Grigorenko, A. Kosterin, V. Pavlinchuk, S. Pisarev, I. lakhimovich, 'Otkrytoe pis'mo "Kommunistam Chekhoslovakii, ko vsemu chekhoslovatskomu narodu"', 28 July 1968.

${ }^{99}$ Bazhan, "'Praz'ka Vesna"', pp. 84, 94-6.

100 D. Zisserman-Brodsky, Constructing Ethnopolitics in the Soviet Union: Samizdat, Deprivation, and the Rise of Ethnic Nationalism (New York, 2003), p. 197.

101 SDS, Document AS970, Chlen spilki pysmennykiv Ukrainy, 'Lyst do Olesia Honchara i sekretariv SPU pro kul'turni vidnosyny mizh Ukrainoiu i ChRSR', 1968.

102 DALO, f. P3, op. 10, s. 248, ark. 87-89.

${ }^{103}$ Bazhan, "'Praz'ka Vesna"', p. 90. 
104 The most violent nationalist resistance to Soviet rule in western Ukraine occurred in the 1940s and early 1950s. See A. Statiev, The Soviet Counterinsurgency in the Western Borderlands (Cambridge, 2010). As Amir Weiner writes, in 1968 'there was no young and violent constituency similar to the returning nationalist guerrillas and underground activists who tried to seize the moment in 1956'. Weiner, ‘Déjà Vu’, p. 186.

105 They thus referred to one culprit as a 'famous nationalist'. Bazhan, "'Praz'ka Vesna"', p. 97.

${ }^{106}$ Bazhan, '"Praz'ka Vesna"', pp. 71-2.

107 TsDAHO, f. 1, op. 25, s. 38, ark. 141-143.

${ }^{108}$ Bazhan, "'Praz'ka Vesna"', p. 90.

109 Bazhan, '"Praz'ka Vesna"', pp. 97-8.

110 Dmytruk, Ukraina, p. 228.

111 Weiner, ‘Déjà Vu’, pp. 159-94.

112 'Zayavlenie Sovetskogo Soyuza', Pravda, 5 December 1989, translated in Navrátil et al. (eds), The Prague Spring, p. 576.

${ }^{113}$ For a critique of this paradigm of stagnation, see Wojnowski, The Near Abroad, pp. 23-5.

${ }^{114}$ For a discussion of the 'ageing revolution', see Weiner, 'Déjà Vu', pp. 159-94.

115 TsDAHO, f. 1, op. 31 , s. 3607 , ark. 1-9.

116 Wojnowski, The Near Abroad, pp. 141-73. 